\title{
Sam Shepard and the "True" West
}

\begin{abstract}
The theateer of Sam Shepard has almost emblematically been considered the epitome of the American, particularly the Southwestern, myth of the frontier and, hence, the vastness and masculine expansiveness it traditionally symbolizes. However, Shepard's theatre attains, I believe, its true potential only when approached in the perspective of the (Neo)Baroque paradigm. Therefore, this article will indicate an alternative manner of interpreting his dramatic thought; the manner, which, as I will argue, allows for re-contextualizing the position of Shepard on the American stage.
\end{abstract}

Keywords: Sam Shepard, family, (Neo)Baroque, major/minor strategy, representation, theatre, drama

The theater of Sam Shepard has almost emblematically been considered the epitome of the American, particularly the Southwestern, myth of the frontier and, hence, the vastness and masculine expansiveness it traditionally symbolizes. As Frederick Jackson Turner pointed out in his "mythopoetic" essays, the frontier, together with the conditions of the frontier life, exerted a profound impact on the American mind and self-perception:

\begin{abstract}
From the conditions of frontier life came intellectual traits of profound importance. The works of travelers along each frontier from colonial days onward describe certain common traits, and these traits have, while softening down, still persisted as survivals in the place of their origin, even when a higher social organization succeeded. The result is that to the frontier the American intellect owes its striking characteristics. That coarseness and strength combined with acuteness and inquisitiveness; that practical, inventive turn of mind, quick to find expedients; that masterful grasp of material things, lacking in the artistic but powerful to effect great ends; that restless, nervous energy; that dominant individualism, working for good and for evil, and withal that buoyancy and exuberance which comes with freedom - these are traits of the frontier, or traits called out elsewhere because of the existence of the frontier. (The Frontier in American History)
\end{abstract}

The national implications notwithstanding, Shepard's theater attains, I believe, its true potential only when approached in the perspective of the (Neo)Baroque paradigm. Therefore, this article will indicate an alternative manner of interpreting his dramatic thought; the manner, which, as I will try to show, allows for re-contextualizing the position of Shepard on the American stage.

The year 1989 saw the publication of Susan Harris Smith's article entitled "Generic Hegemony: American Drama and the Canon," in which the author, while referring to the status of American drama, considered it "an unwanted bastard child" (112) of the American literary tradition epitomized, as it has been believed, by canonical fiction and poetry. What is more, in the 1997 monograph, American Drama: The Bastard Art, Smith advanced even a more radical thesis by claiming that 
"American drama [was] deliberately buried alive in the cover-up of what was perceived embarrassedly and fearfully as a vital manifestation of cultural provincialism, feminine emotion, and unstable radicalism" (11). It thus comes as no surprise that the approach to the American dramatic arts was frequently confined to derogatory remarks on its "enfeeblement" or "mindlessness" (qtd. in Schroeder 420).

The opinion that the English stage was the only legitimate representative of the high culture when it comes to the theater realm in English-speaking countries contributed to the American drama being demoted to the locus of provincial folly — such an opinion was bitterly summarized by Richard Gilman who stated that "[t]he American drama [was] itself almost mindless" (qtd. in Smith, American Drama 10). ${ }^{1}$ However, those strenuous efforts to maintain a view of the generic hierarchy in American literature seemed to be a futile endeavour in, to invoke Patricia R. Schroeder's observation, such a heterogeneous society (423). Appositely, I would propose to recognize Sam Shepard's drama Buried Child as a representative (Neo)Baroque play that materializes the structural and thematic tensions between both the canon (the major strategy) and its critique (the minor strategy); the presentation of characters and their initial acts (the major strategy) and re-definition of their functioning in the play (the minor strategy).

The origins of both the major and minor strategies, which William Egginton applies to his analysis of the baroque aesthetics, are to be traced back to Deleuze and Guattari's discussion of Franz Kafka's work. This eponymous philosophical concept that both scholars introduce in Kafka: Toward a Minor Literature (1975) does not posit "a minor language" as the source of "a minor literature;" rather, minor literature is "that which a minority constructs within a major language" (16). ${ }^{2}$ By grounding its existence in a "deterritorizalizing" facet of language, the literature designated as "minor" "leav[es] behind normal structures of sense by following the 'lines of flight' or escape that such language inevitably carries with it" (Egginton, The Theater of Truth 27). Hence, Egginton's idea of the minor strategy always already entails the major strategy being at work in the same material as the minor strategy is - hence, it is impossible to discuss them separately.

1 In the article "Lag and Change: Standards of Taste in Early American Drama," George Winchester Stone, Jr. proposes an interesting theory of the development of the early American drama. Invoking Allardyce Nicoll, "the dean of English drama historians" (338), that the English theater was extremely unwilling to accept the influences from the continent, hence the lag in acknowledging the Italian, German, and Scandinavian impulses, Stone coins the phrase "secondary lag" for designating the process that took place on the emerging American stage. He explicates that it was an incessant movement of "English repertories, actors, and managers" (338) to the New Land in the late eighteenth and early nineteenth century that "helped mould public taste" (338) in American theaters.

2 In the Introduction to the volume on the Gothic mode's indebtedness to Shakespeare's works, John Drakakis also acknowledges Deleuze and Guattari's notion of "minor" literature and posits the legitimacy of its use in the context of Gothic writing (10-12). For further discussion of Shakespeare's significance to the Gothic convention, see Gothic Shakespeares, ed. John Drakakis and Dale Townshend. 


\section{The Modern Baroque Theater}

The use of the term "baroque" in the discussion of dramatic arts might be construed as an act of further enhancing the elusiveness of this already ephemeral phenomenon. ${ }^{3}$ Indeed, to invoke, for instance, Anne Ubersfeld, theater "is both eternal (indefinitely reproducible and renewable) and of the instant (never reproduced identically). It is an art involving instances of performance that are bound to a given moment or day and cannot be the same the next day" (3). This singularity of a dramatic performance legitimizes Ubersfeld's further statement that, at least in principle, the only constant entity in the theater is the very dramatic text (the script), which is to be realized on the stage (3). ${ }^{4}$ On the other hand, while considering the semiology as the "theory of the existent," Julia Kristeva presents a substantially more radical viewpoint, declaring that the "modern theater does not exist - it does not take (a) place [since] its semiology is a mirage" (277). It is therefore language-le langage - that epitomizes the only inhabitable locus of interplay for the modern human beings' experience. Kristeva claims that

[s]ince no set or interplay of sets is able to hold up any longer faced with the crises of state, religion, and family, it is impossible to prefer a discourse - to play out a discourse - on the basis of a scene, sign of recognition, which would provide for the actor's and audience's recognition of themselves in the same Author.... As its only remaining locus of interplay is the space of language, modern theater no longer exists outside of the text. (277)

However, Kristeva also declares that the text of a play is to be regarded not as a perfectly homogenous entity but "a permutation of texts, an intertextuality [since i]n the space of a single text several énoncés from other texts cross and neutralize each other" (qtd. in Elam 93). ${ }^{5}$ The analysis of a dramatic text cannot thus ignore the existence and impact of discourses on each other and the whole performance as well.

3 In the article "Philip Massinger's The Roman Actor and the Semiotics of Censored Theater," Andrew James Hartley speaks about the characteristic "instability of theater" (361). The concept of "instability" and its role in Buried Child will be dealt with in the further part of this article.

4 "But surely the text, at least in theory, is intangible and forever fixed" (Ubersfeld 3). Nevertheless, the idea of a dramatic text's invariability seems to be put in question by Tadeusz Różewicz and his manner of exploring the potentiality of both the theater and drama. Having written the early plays during the censorship imposed by the communist government, Różewicz did change his works, e.g. Kartoteka rozrzucona - once the censorship ended — was re-written back, as Robert Looby puts it, "to what, presumably, they would have been if it had not been for the censor." Moreover, Looby continues, the variability of Kartoteka's script is built into the text of the play by means of stage directions that force the director into making a choice (e.g. "the curtain falls or it does not fall')."

5 It seems worth noting here the epistemological shift of emphasis from the stage to the page, which Timothy Murray examines in Theatrical Legitimation: Allegories of Genius in SeventeenthCentury England and France. While analyzing the approach to theater and drama both in England and in France in the seventeenth century, he concludes that it was the contemporary public theater that "nurture[d] significational free play and intertextuality, [whereas] the printed text offer[ed] the playwright the opportunity to transcend authorial anonymity and linguistic ruin through various operations of textual self-representation. The textual materialization of authorship thus enacts the regeneration of the figure of the Self through its objectification in the printed text" (16). 
If "the space of language" is seen as the only valid "locus of interplay" in the discussion of the modern theater, where the premises of semiotics operate, it is possible to claim that the abundance of intertextual relationships and permutations discerned in the space of a single dramatic text induces tensions between those coexisting discourses. Incapable of identifying unequivocally with the only one dominant discourse as "the space of language," the dramatic text has to acknowledge other discourses as well. José Lezama Lima's inquiry into the baroque poetics may shed light on these ambiguous tensions in the dramatic text. Although achieving the desired unity of arts, the baroque cannot be confined, Lezama Lima argues, within the frame of one exegesis. The emerging "tension[s] of the Baroque" (qtd. in Egginton, The Theater of Truth 71) emphasize the significance of the components.

Constituting a vital element of any dramatic text, the clashing discourses epitomize Egginton's idea of the baroque tension as the one "between two directions or strategies... a centrifugal versus a centripetal force, a major versus a minor strategy, a molar versus a molecular vector (The Theater of Truth 71). I would propose to categorize the discourses that can be discerned within a single dramatic text according to their correspondences with centrifugal/centripetal forces; major/minor strategies; molar/molecular vectors. The criterion adopted for placing discourses in a particular category will be based on each discourse's relation to the fundamental baroque dilemma, that is, a relationship between the representation and the notion of a reality concealed behind it or a lack thereof.

\section{How the Minor Strategy Meets the Major Strategy}

In applying Egginton's viewpoint to the analysis of the modern drama, the discourses and the characters who embody them will be recognized as those that "assum[e] the existence of a veil of appearance, and then sugges[t] the possibility of a space opening just beyond those appearances where truth resides" (The Theater of Truth 3, emphasis mine), i.e. the possibility described by Deleuze and Guattari as "major." These discourses are considered representative of Egginton's re-interpretation of the major strategy. Nonetheless, a dramatic text is also permeated with other discourses and inhabited by other characters whose construction is subordinate to the representation itself. Having thus "nestl[ed] into the representation and refus[ed] to refer to... some other reality, but instead affirming it [representation], albeit ironically, as [the] only reality" (The Theater of Truth 6), these discourses and characters represent the minor strategy. Therefore, "the tension of the Baroque" refers here to the phenomena occurring between the major and minor strategies.

I would propose to consider the "tension of the Baroque" a phenomenon

6 Egginton claims that such an approach to major strategy supports "to some extent Walter Benjamin's thesis that modernity is founded on a sense of melancholy for the loss of tradition, the past, and the stability it offers, and that the aesthetic sign and origin of this melancholy is the Baroque" (The Theater of Truth 132). A parallel observation was made already in 1935 by George Williamson who, having inquired into the cause of melancholy and mutability, affirmed that their origins were to be found in the contemporary firm conviction about the unbridled decay of the world, which, according to Benjamin, was also the epitome of the seventeenth-century sense of instability ("Mutability, Decay, and Seventeenth-Century Melancholy"). 
generated by the mutual embeddedness of the two strategies, whose clashes create liminal spaces. ${ }^{7}$ The incessant collisions of different versions of "truth" emerging from a particular dramatic text initiate a rise of a spatial relationship between the major and minor strategies, which obscures their difference and generates the interstitial space, that is, the "in-between" space imbued with the premises of them both.

It is at the boundaries infused with the potentialities of those two combating strategies that the possible "truths" are generated. Since one strategy (major) strives for imposing its own "veracity," while the other (minor) multiplies its representations and severs the representation's links to the "ultimate truthfulness," the excess seems to be an inevitable consequence. The foregoing discussion on excess draws on Omar Calabrese's idea of this concept, which "describes the overcoming of a limit in terms of an exit from a closed system. Excess escapes by breaking through. It crosses the threshold by making an opening, a breach" (49). Therefore, the collisions between the boundaries of the involved strategies "upset" a seeming immutability of the view of reality held by the major strategy and, as a result, generate the excess of the possible "truths."

What is more, the focus on the boundaries also resembles a Gothic strategy of organizing the universe by erecting borders, where the "legitimate," "proper," and "sane" are discriminated from the "illicit," "indecent," and "lunatic." The very existence of the borders, both the material and spiritual ones, generates, nevertheless, "the possibility of transgression and suggest[s] the proper punishment for those rebels who cross them, who 'go too far': to be immured, incarcerated, imprisoned, in the attics, dungeons, or secret chambers of the family or the state" (Williams 12). The idea of the boundary and boundary-transgression endows the Gothic space with a purely geometrical dimension, thus making possible its description in quasi-mathematical terms. Similarly to the principles pertaining to mathematical sets, their borderlines, which separate set $\mathrm{A}$ and set B - as far as intersecting sets are concerned - belong both to the set A, and to the set B. Therefore, it is impossible to state with absolute certainty where the end of a space belonging to set $\mathrm{A}$, or where that of a space belonging to set $\mathrm{B}$ is.

As Manuel Aguirre explicates, in the Gothic realm, the very same dilemma pertains to the distinction between the threshold and the Other space that can be done away with as the threshold is already the part of the Other (Aguirre, "Geometria strachu" 20). ${ }^{8}$ Aguirre further suggests that the essence of the threshold lies in its

7 Far from being a stable or unfluctuating process, the idea of the clash between the borders corresponds with the creative processes taking place in Nature as they are also concentrated on incessant change, impermanence and fluidity. Spinoza's principle of natura naturans seems thus to operate within the space of a dramatic intertextual interplay as well. For further references to Spinoza's philosophy, see Warren Montag's Bodies, Masses, Power: Spinoza and his Contemporaries.

8 "rozróżnienie pomiędzy progiem i Inną przestrzenią może być zniesione, bowiem próg jest częścią Innego" (Aguirre, "Geometria strachu" 20). Aguirre also maintains that "[t]he ambiguity of the threshold - limen - is paradoxical in its nature. We stand hesitating on the threshold and don't know whether to cross it or not without realizing that we are already on the Other side. We enter this no-man's-land believing that it is only a transition to the Other but the moment we enter it, we have already entered the Other. Thus, the threshold terrifies us like the reality behind it. The threshold is, both, a place and a non-place, or, as Victor Turner put it, 'a place which is not a 
double ontological nature, which allows for the appropriation and colonization of the limen's borders (Aguirre, "Geometria strachu" 21). That being so, both the Gothic and Egginton's baroque aesthetics converge exactly on that interstitial space which simultaneously belongs to the minor and major strategies. A perfect embodiment of that convergence is, I would suggest, Sam Shepard's drama Buried Child.

\section{"Legitimizing the Bastard Child": The Convergence of the (Neo)Baroque and the Gothic in Sam Shepard's Buried Child}

In the monograph on Sam Shepard's theatrical aesthetics, Stephen J. Bottoms maintains that the playwright conflates in his works "the 'high' or 'romantic' modernis[m], the 'late' modernis[m], and... the reluctant postmodernism" (4), thus following the formal principles of constructing a collage. Ramesh Prasad Panigrahi also recognizes "a collage character" in the playwright's dramas, which he defines as "an amalgam of a variety of extreme mood states, roles, fantastic deformations and symbolic compositions" (18-19). ${ }^{10}$ Since a collage is composed of the material fragments that conventionally vary in texture, volume and density, Shepard's theater seems to pertain to analogous premises because it is built of

fragments, and often of verbal and visual glut, in which disparate elements butt against each other in abrupt or unsettling juxtapositions, and in which intense, disturbing confrontations are inextricably entwined with a certain playfulness and madcap comedy.... This inclusive approach often makes the plays seem unwieldy or somehow incomplete, yet onstage it is also this very 'flaw'-the lack of structural or thematic resolution-which makes his best works so provocative.

(Bottoms 2)

Those attributes make Shepard's works the embodiment of postmodernism, or, as Bottoms suggests, the "reluctant postmodernism" for, "by accident or design - the plays have become gradually more sophisticated in their handling of the kind of disruptive, unresolved formal qualities typical of postmodernist art" (11). ${ }^{11}$

place,' both this and that or neither this, nor that" (“Geometria strachu” 20-21, translation mine). ["W tym tkwi problem dwuznaczności limen — progu, w jego paradoksalnej naturze. Stoimy pełni wahania, czy próg ten przekroczyć—i jesteśmy jednocześnie już po Drugiej stronie. Wkraczamy na ziemię niczyją traktując ją tylko jako przejście, które wiedzie do Innego: jednak wkraczając nań wkroczyliśmy już w Inne. Stąd sam próg przeraża nas tak samo, jak rzeczywistość leżąca za nim. Dlatego próg jest i miejscem, i nie-miejscem zarazem, czy też, jak ujął to Victor Turner, 'miejscem, które miejscem nie jest', zarówno tym, jak i tamtym, lub ani tym, ani tamtym.']

9 The play is considered the second movement in Shepard's "family trilogy" that consists of Curse of the Starving Class (1977), Buried Child (1978) and True West (1980). Nonetheless, as Thomas P. Adler posits, a quintet might be created out of the dramatic trio by means of completing it by two corresponding movements, that is, Fool for Love (1983) and A Lie of the Mind (1985) (111).

10 For further discussion of the psychological/psychoanalytical examination of Shepard's characters, see his The Splintered Self: Character and Vision in Sam Shepard's Plays. For further analysis of Shepard's fragmenting both the characters and the dramatic action, see Gay Gibson Cima's "Shifting Perspectives: Combining Shepard and Rauschenberg."

11 While pondering upon the idea of dramatic realism, Michael Vanden Heuvel proposes an interesting 
However, those "unresolved formal qualities" and a defective construction which resembled "a posture that has not yet grown into a cohesive play" (qtd. in Bottoms 153) were initially the reason for the play's severe criticism. The strongest condemnation of Buried Child was expressed by Walter Kerr who, in the scathing review of the drama entitled "Sam Shepard: What's the Message?" and published in The New York Times on the $10^{\text {th }}$ of December, 1978, criticized the playwright for not presenting the audience with, as Bottoms summarizes it, "a cohesive message" (153), which would be in accordance with the premises of domestic naturalism. Such a designation of Shepard's dealings with the dramatic art once again evokes a baroque problem of the relationship between the major and minor strategies. That being so, I would argue that labelling Buried Child as the epitome of the postmodern drama (Bottoms 152) or the antagonist to "drama proper" (Kerr) is a simplification which can be overcome by adopting Egginton's (Neo)Baroque paradigm and his idea of the major/minor strategy dynamics.

Act $O \mathrm{On}^{12}$ of this drama ${ }^{13}$ opens with the stage directions that delineate the stage design, which is manifestly not consonant with the emblematic form of the Rockwellean bliss: ${ }^{14}$ the playwright sets his play in a dilapidated room in an eerily

analysis of the "text-oriented playwrights, the absurdists, and especially Beckett," among whom he places Shepard as well, designating his dramas as "hybrid texts." The critic argues that "[a] 11 of these artists, while maintaining elements of conventional realism, have found unique ways to express the sense that the old tonal coherence and competencies of the traditional texts of classic realism have been irretrievably lost, and each has moved closer toward the realization of hybrid texts that maintain a semblance of classical order while they simultaneously invest in the strategies of performance to destabilize those texts" (54).

12 Apart from the division into the acts, there are no separate scenes in the play.

13 Buried Child had its premiere on the $27^{\text {th }}$ of June, 1978, at the Magic Theater in San Francisco, where Shepard was the playwright in residence from 1974 to 1984 . The drama was directed by Robert Woodruff with the following cast: DODGE - Joseph Gistirak; HALIE - Catherine Willis; TILDEN - Dennis Ludlow; BRADLEY - William M. Carr; SHELLEY - Betsy Scott; VINCE - Barry Lane; FATHER DEWIS - Rj Frank. Founded in 1967 by John Lion, a Graduate student at the University of California, Berkeley, who worked under the tutelage of Professor Jan Kott, the Magic Theater formulated its artistic credo on the grounds of Lion's enchantment with "the Off-Off-Broadway model of intimate, informal atmosphere, the promotion of experiment, and (crucially) the right to fail" (Bottoms 126). Therefore, when moved into San Francisco from the contemporary locations in Berkeley, the Magic - as the theater is frequently called - became the centre of San Francisco's theatrical experimentation and "dr[ew] on a rich pool of young acting talents for its dramatic productions, including now-established names like Ed Harris, Amy Madigan, and Danny Glover" (Bottoms 126). The artistic collaboration between Sam Shepard and John Lion begun when Lion took residence in San Francisco, and continued successfully till 1984.

14 On every occasion critics and scholars discuss Shepard's literary preoccupation with the concept of the American family. In the interview granted Matthew Roudané on the $5^{\text {th }}$ of May, 2000, in St. Paul, Minnesota, the playwright articulated his viewpoint on that theme and admitted that " $[t]$ he one thing that ke[pt] drawing [him] back to it [was] this thing that there [was] no escape from the family. And it almost seem[ed] like the whole wilfulness of the sixties was to break away from the family: the family was no longer viable, no longer valid somehow in everybody's mind. The 'nuclear family' and all these coined phrases suddenly became meaningless. We were all independent, we were all free of that, we were somehow spinning out there in the world without any connection whatsoever, you know. Which [was] ridiculous. It [was] absolutely ridiculous to intellectually think that you [could] sever yourself, I mean even if you didn't know who your 
isolated, deteriorating homestead that heretofore has been a part of a flourishing farm. ${ }^{15}$ The sparse furnishings as well as any other elements in the room are either "old," e.g. "[o]ld wooden staircase" (I:63), "old, dark green sofa with the stuffing coming out in spots" (I:63), or do not function properly, e.g. "a large, old-fashioned T.V. [emitting solely a] flickering blue light... but no image, no sound" (I:63). Notwithstanding the information in the stage directions that the play is to begin in the daytime, the hues of colours used for describing the furniture onstage stand in striking contrast to those, which are normally associated with this particular time of the day. There is no mention of intense and light colors; each one of them is either "pale," e.g. "pale carpet" (I:63), or "dark," e.g. "dark green sofa" (I:63), "dark elm trees" (I:63).

Furthermore, the remark about "the shapes of dark elm trees" (I:63) in the background introduces intertextuality in the play as it is a direct allusion to Eugene O'Neill's Desire Under the Elms (1924). However, thus initiated intertextual allusion is not limited to the elm reference because, analogously to O'Neill's play, Shepard's drama presents a story "of darkly destructive family traits repeating themselves down the generations" (Bottoms 157). Bearing in mind Egginton's emphasis on the differentiation between the major/minor strategy, I would argue that already the very beginning of Buried Child suggests the operation of the major strategy, which, as mentioned earlier, "assumes the existence of a veil of appearances, and then suggests the possibility of a space opening just beyond those appearances where truth resides" (The Theater of Truth 3). The "veil of appearances" is to be discerned, I believe, in the representation of an allegedly ordinary room of a western house, where, indeed, the basic equipment is installed. However, the faded colours that probably were to camouflage the veracity, together with various medicines scattered on the small table and shabby furnishings indicate that "the reality hidden behind [that, which is a representation]" (Egginton, The Theater of Truth 6 ) is far from being the ordinary and peaceful one. The truth emerges like "the stuffing coming out in spots" (I:63) from the old sofa-it discloses itself gradually, yet incessantly, and seems to envelop every piece of equipment and each of the characters that appear on the stage. It appears that the truth must be connected with the revelation of the family's horrifying secret. Nevertheless, since the moment of his appearance, Dodge, a patriarchal figure, strives

mother and father were, if you never met them, you [were] still intimately, inevitably, and entirely connected to who brought you into the world - through a long, long chain, regardless of whether you knew them face to face or not. You could be the most outcast orphan and yet you [were] still inevitably connected to this chain" (qtd. in Roudané 67-68). Norman Rockwell, in turn, was called the most beloved illustrator of America who, as Steven Spielberg asserted in the American Master's series, "painted the American dream - better than anyone." Rockwell created 317 covers for The Saturday Evening Post and was the author of a series of the 1943 oil paintings entitled The Four Freedoms (or Four Essential Human Freedoms), which were reproduced and distributed during the World War II in the form of propaganda posters by the Office of War Information. The admiration of the public notwithstanding, the works of Rockwell's were dismissed by most critics as devoid of artistic merit and true-to-life social reflection.

15 Rodney Simard's insightful analysis of the drama allows him to venture a hypothesis that the play is "a postmodern dramatization of "The Wasteland" (87).

16 From now on the numbers in brackets (I:63) will refer to the act followed by the page number. 
to conceal those clear manifestations of the minor strategy's operation. ${ }^{17}$

This male character, who seems to perceive his "paternity only as a phallic exercise of potency" (Auerbach 44), does literally crusade for retaining his position as the ruler of the house as it is the only way to prevent the secret from being uncovered. Yet, surprisingly, by celebrating the representation of the world he lives in as the only reality, he embodies, I would suggest, the minor strategy as well. Moreover, his desire seems to mirror the yearning of absolute monarchs of the Baroque era who wanted to preserve their image of absolute patriarchs. That is why, to invoke Kristiaan P. Aercke's observation made in Gods of Play: Baroque Festive Performances as Rhetorical Discourse, they organized splendid performances which

acted as one of the most powerful agents that could draw a court together (and thereby define the microcosm of that court-world vis-à-vis the macrocosm of the world beyond) in an at least temporarily stable communion around the figure of the sponsor-ruler, who alone could provide the sort of 'mediation' that Bataille ${ }^{18}$ considers a necessary factor in the interattraction between people.... We might say that essential fear of the ruler kept the court together, and that the splendid festive performance served as an unusually privileged and significant means of placating the shared source of fear-which leads us back to the notions of serious (even cultic) play and sacrifice. (5)

Dodge equally wants to be a "God of Play" and hankers after instilling the same "cultic" fear as the baroque rulers did. Like a monarch on the throne, he also occupies the central part of the room/stage but, in defiance of the status of the king, he faces a TV set that is out of order, sips cheap whiskey rather than the finest alcoholic beverage, and must hide the bottle under the "old brown blanket" (I:63), rather than the royal ermine robe.

Notwithstanding the efforts, Dodge, the "king," is no longer young and powerful but "very thin and sickly looking, in his late seventies" (I:63), and his formerly rich robes transformed into "a well-worn T-shirt, suspenders, khaki work pants and brown slippers" (I:63). What is more, Dodge's absolute authority is further undermined by his wife's voice incessantly pestering: "Dodge! You want a pill, Dodge" (I:63), "What're you watching? You shouldn't be watching anything that'll get you excited! No horse racing!" (I:65). The juxtaposition of the baroque ruler's attributes and Dodge's peculiarities makes feasible an assertion that his endeavours to maintain the absolute control of the major strategy is an internally contradictory aim since this character is equally permeated by the elements of the minor strategy that he tries so desperately to suppress. Therefore, in spite of focusing on the representation of the "patriarchal legacy" (McDonough 65), Dodge's senile impotency only proves that he remains under the rule of both the major and minor strategies. Hence, a dual character of Dodge's personality does generate a particular form of what Lezama Lima refers to

17 Designating the character of Dodge as a mere "source of the play's comedy" (Krasner 109) is, I believe, a simplification. A peculiar laugh that this dramatic persona might evoke is much more in the vein of quasi-Fletcherian hopelessness (Blau 280) than just a comic foolishness.

18 In the quotation, Aercke refers to George Bataille's "Collège de sociologie" (309-311) from the second volume of Oeuvres Complètes, ed. Denis Hollier. 
as the "tension of the Baroque" because it conflates in itself both strategies, although, it must be stressed, the playwright initially shapes this character as the figure who epitomizes only the major strategy.

At first, Halie, Dodge's wife, seems to be created for the same purpose as Dodge is, that is, to demonstrate the premises of the major strategy, which would enable the family secret to be kept unrevealed. Therefore, she enacts the major strategy by cultivating a glorious past of the house's golden age. Nestled in the room on the first floor of the building that is not visible on the stage, she keeps maintaining appearances, which is typical of the major strategy, by displaying pictures of the formerly wealthy, land-owning family. Halie's presence is initially conveyed solely through her disembodied voice projected from the offstage space stretched out somewhere beyond the visible top of the staircase. Yet, that very act of her being relegated to the marginalized unseen locus seems to suggest that the preservation of the major strategy is only possible from the area which is not exposed to the gaze of the others, and, paradoxically, can be identified with the minor strategy's field of operation.

Halie's anticipated appearance onstage only enhances the collision between the major strategy represented by her and that of Dodge's fantasy. In American Drama and the Postmodern: Fragmenting the Realistic Stage, David K. Sauer seems to advance an analogous thesis not referring, however, to the (Neo)Baroque aesthetics. Nevertheless, his observation on the language Shepard employs in this drama unmistakably invokes the tension between the major and minor strategies:

[i]n Shepard's play, characters make... assertions, which seem to be declarative statements of fact or feeling, but in truth they are not, as [, for instance,] the opening dispute about horse racing demonstrates. That scene offers assertion and counter-assertion as each seeks to impose his or her view of the past on the other. From the outset there is no literal truth here for the audience to determine. Rather, the two struggle for dominance over each other, pretending that they are talking about a real event. But the audience will never know who is telling the truth, and the literal truth is not the issue here. (202)

Assuming the role of a respectable matron bewailing the loss of both the beloved son, Ansel, and Dodge's impaired ground-floor dominion, she believes that those desperate acts will protect the representation of reality she has designed. However, though their aims are the same, Halie's manner of mediating her "reality" collides with the one advocated by her husband, thus creating a tension which provokes other characters to reveal their own versions of reality. Yet, it is the abrupt appearances of Tilden, an allegedly mentally deranged oldest son, and Bradley, an automaton-like amputee with a wooden leg, that initiate the final overthrow of the hegemony of the major strategy represented by Dodge and by Halie. Having perversely mutilated his father by almost completely scalping him off, Bradley, in a Samson-like Jacobean manner, deprives Dodge of his power and, as a consequence, the strength to defend his fantasy. The final overthrow, however, is performed by Tilden who eventually discards both the father's and the mother's representations of reality.

When appearing for the first time on the stage, the oldest son carries "the ears of corn in his arms" (I:69) that he has picked "right out back" of the house. In the 
discussion of the theatrical objects and their function on the English Renaissance stage, Douglas Bruster points out that even "[i]n early modern illustrations, hand properties seem not the exception but the rule" (74). He validates his theory by invoking the baroque concept of horror vacui and its connection with keeping the figures' hands always occupied:

[i]llustrators preferred that hands be used for gestures, or rest on something, or grasp an object, rather than remaining empty. Whether we explain this tendency through content (through what a hand held) or process (through the fact that a hand was doing something), illustrations connected with the early modern stage routinely feature characters holding things. (74-75)

Appositely, Shepard seems to follow the principle mentioned above in constructing the figure of Tilden whose hands are never empty, either. What is more, particular dramatic genres also specified "not only the number but the kinds of props which appear on stage" (79). Thus, Bruster continues, "certain kind of properties serve as generic signals: a lute or a hobby horse might signal a comedy, a skull or a dagger a tragedy. And knowing the genre of a play can lead one to expect it to feature certain properties" (79). The morbid crops and the muddy package Tilden carries in the final act suggest that the play is tragic, rather than comic. Such a hypothesis seems to find its confirmation in the fact that the ground in the back of the house has been infertile for over thirty years, the phenomenon which Dodge remembers to comment on: "There hasn't been corn out there since about nineteen thirty-five! That's the last time I planted corn out there!" (I:69). Halie and her vehement denials of a very possibility of the crops' flourishing in the back of the house instantly create an aura of conflating the established temporal dimensions related to, for instance, seasons, and institutes an incessant overlapping of seemingly exclusive phenomena, such as lack and plenitude, past and present, memory and forgetting, abundance and insufficiency.

Appositely, Carlos Fuentes points out that "[t]he Baroque language of abundance, is also the language of insufficiency: only those who possess nothing include everything. Their horror of vacuity is not gratuitous; it is due to the certainty of the fact that one is in emptiness, that one lacks security" (qtd. in Egginton, The Theater of Truth 73, emphasis in the original). Following Fuentes' thesis, I would claim that Buried Child's perplexing language of abundance, e.g. "tons of corn" (I:69), "Back yard's full of carrots. Corn. Potatoes" (II:93), in reference to the previously infertile ground, is simultaneously the language of insufficiency, and, hence, an actual embodiment of a (Neo)Baroque idea. That paradoxical co-existence of the doublenatured language in the play seems to justify a comparison of the language use with the operations of the two strategies that are clearly visible in the drama. Shepard's language of abundance coincides with the minor strategy, which strives for preserving the representation as the only reality, whereas the language of insufficiency corresponds to the major strategy that is intent on not letting anyone in on the secret hidden behind the veil of fertility and bountifulness.

The plenitude of crops is universally recognized as the prognostication of a sumptuous feast, and designated by Mikhail Bakhtin as the "triumph of life over 
death" (qtd. in Bednarek 10, translation mine) ${ }^{19}$ Notwithstanding, Bogusław Bednarek also points to the fact that not every feast symbolizes Bakhtinian celebration and notes that there were also the "infernal banquets" that took place, as the bygone beliefs hold, in the infernum's abyss. ${ }^{20}$ Therefore, the expected feast that is to be held in Buried Child seems to be more of the "infernal banquet" than the "triumph of life over death" as the crops have grown on the ground fertilized by the decomposing body of Halie's illegitimate child, which was a disgrace she wanted to conceal. However, the status of that death-over-life triumph is an ambivalent one because Bakhtin's portrayal of feasts is invariably identified with the "moments of crisis, of breaking points in the cycle of nature or in the life of society and man.... [m]oments of death and revival, of change and renewal" (9). Hence, the very existence of "death" induces "life" because both phenomena are interdependent and cannot function without each other. That is why the notion of the "infernal banquet" allows to re-consider the child's death in the Bakhtinian perspective since its murder and grotesque decomposing corpse might equally symbolize the very restoration to life.

Initially a carefully constructed human being, the child's decomposing body becomes the "formless form," which "produces a phenomenon of suspension and neutralization, since we are currently dealing with a being that is neither 'well formed' nor "deformed" (Calabrese 97). It subverts the ontological certitude of an internal integrity, thus becoming the epitome of the first level of instability, which manifests itself in the (Neo)Baroque aesthetics in terms of represented "themes and figures" (Calabrese 105). As the materialization of Lezama Lima's "tension of the Baroque" generated by the final clash between the minor and the major strategy, the buried child not only signifies the ultimate eradication of what can be interpreted as the major strategy, that is, Dodge's and Halie's celebration of their fantasies, but also constitutes a link between Tilden's ostensible retardation and the family's hypocrisy.

Indeed, it is Tilden who acknowledges an indecent status of his incestuous relationship with his own mother, yet also realizes the horrid cruelty of drowning the infant by his betrayed father. Since the baby's tiny body is, as Inverso declares, "simply the matrix of - not the reason for-defilement [and is to be recognized as] a kind of 'fault' in the geological rather than in the moral sense, a crack in the otherwise seamless surface of things, from which shock waves radiate outward" (151), it is this contagion generated by its decomposing body that is capable of destroying the family's illusionistic, artificial representation of reality.

While discussing the idea of death in the context of infancy and history, Giorgio Agamben observes that it is not only the state of death but also the act of birth that generates the "unstable signifiers":

just as death does not immediately produce ancestors, but ghosts, so birth does not immediately produce men and women, but babies, which in all societies have a special differential status. If the ghost is the living-dead or the half-dead person, the baby is a dead-living or a half-alive person. It too, as a tangible proof of the

19 "triumf życia nad śmiercią" (qtd. in Bednarek 10).

20 "napomknijmy o 'bankiecie piekielnym' odbywającym się-wedle dawnych wierzeń-w otchłaniach infernum" (qtd. in Bednarek 10). 
discontinuity between the world of the living and the world of the dead, and between the diachrony and synchrony, and as an unstable signifier which can, at any moment, be transformed into its own opposite, thereby represents both a threat to be neutralized and a means enabling a passage from one sphere to the other without abolishing its signifying difference. And just as ghosts have a corresponding function to that of children, so funeral rites correspond to initiation rites, in their purpose of transforming the unstable signifiers into stable signifiers.

Hence, the threat posed by the flesh of the bastard infant is to be recognized in its potentiality for signifying "a passage from one sphere," that is, the major strategy, to the minor strategy's representation. Aware of this menace, Dodge, in order to preserve the external propriety, has to eliminate this disturbing being: "We couldn't let a thing like that continue. We couldn't allow that to grow up right in the middle of our lives. It made everything we'd accomplished look like it was nothin'. Everything was cancelled out by this one mistake. This one weakness" (III:124).

Tilden's act of unearthing the "formless form" of the murdered child's decomposing body concealed in the offstage space does annihilate the family's endeavours and signifies, through this invasive movement, the "encroachment by the diegetic realm into mimetic space" (Inverso 153). ${ }^{21}$

Having explored the work of the offstage space in the seventeenth-century French theater, John D. Lyons considers this absent space an area where both literal and figurative functions are fulfilled (73). The critic declares that entering to the unseen site is possible solely by crossing the threshold of characters' narratives, which shape both the spectators' ideas of the offstage space and the onstage characters (77). What is more, Lyons asserts that

[b]y reminding ourselves [the spectators] of the physically nonexistent nature of the offstage space, we can perceive the fact that what we hear in the récit is what the character believes, wishes, or fabricates - not what is. Far from being the 'crude reality' which, in Spitzer's description, is filtered by the narrative, the content of the récit gives the image of the recesses of the character who presents the narrative. At times this process advances to the point of undermining all credibility of the character [and the dramatic event/dramatic phenomena as well], of isolating him with his private account, his private 'elsewhere,' within the public world of the stage. (77-78)

Therefore, I believe that Shepard's treatment of the offstage space is equivalent to Issacharoff's idea of the invisible, which "invades and finally overcomes the visible" (61). Therefore, this (Neo)Baroque excess emerging in the offstage space spreads to the onstage space with Tilden carrying the child's decomposing body that, to quote

21 The concept of the diegetic space (the off-stage space) is to be understood here in the context of Michael Issacharoff's thesis, according to which the diegetic space is "described, that is, referred to in the dialogue, and therefore confined to a merely verbal existence" (58, emphasis in the original). That being so, I would consider that diegetically understood backstage not a neutral medium but a heterogeneous area where the phenomena ostensibly absent from and indiscernible on the stage are set. 
Deleuze, "does not really vanish, but folds in upon itself, abruptly involuting into the again newly dormant seed by skipping all intermediate stages" (8). The "formless form" of the child's grotesque corpse is indeed the materialization of that diegetically approached backstage space.

While analysing the dramatic performance in Shepard's dramas, Florence Falk asserts that the playwright's works "constitute the American Family Album, [with] its members caught in various poses - frozen like the volcanic victims at Pompeiias they try to perform their way out of, or around, disaster" (182). That being so, I would also suggest that Shepard's characters, having indeed strived for creating "other scenarios within the main storyline of the play" (Marranca 20), and thus inducing "not the play-within-the-play [structure] but play within the play" (Marranca 19, emphasis in the original) ${ }_{,}^{22}$ do in fact crusade for preserving the truth which manifests itself in the major strategy that veils the minor strategy's illegitimate crimes performed by proliferating excess. ${ }^{23}$ That is why it is precisely the minor strategy that epitomizes the real threat to the family's vision of reality.

The drama thus articulates the (Neo)Baroque tension between the "Inside" of undesirable imperfections and disgraceful improprieties, and the "Outside" of appropriate and hence "pure" representations of the defective "Inside." These illicit "Internal" phenomena, veiled by the seemingly righteous "External" representations seem to represent, in turn, Shepard's strangulated voice, which strives for liberation and apprehension. Therefore, these seemingly perfect representations are devised with a deliberate intention of creating the verbal façade that, in spite of epitomizing the decent and, hence, acceptable material (i.e. in opposition to the verbal/diegetic) exteriority, is nonetheless under an incessant threat of being invaded and raised by the suppressed illicit phenomena residing within the realm of the diegetic interiority. What is more, the epistemological chaos arising from the chiasmatic interchangeability of the major and the minor strategies operating in the drama seems to situate Shepard's work within the dynamic continuum of unfolding fold whose seeming ending is, in fact, the new beginning, always "in-between." 24

22 As Patrice Pavis clarifies in his Dictionary of the Theater, the technique of the play within a play concerns a "play or performance whose subject is the performance of the play. The external audience watches a performance within which an audience of actors is also watching a performance" (270). By eliminating hyphens and immediately evoking the notion of performance, Marranca emphasizes the role of the actor in Shepard's plays.

23 Marranca's re-interpretation of the play-within-the-play concept is oriented to incorporating the model of structural analysis to the thematic discussion of dramatic works. That being so, her idea, when considered in the context of Shepard's play, seems to correspond with what Viveca Füredy calls the "intact but reified boundary" (754).

24 It seems worth pointing out that, notwithstanding a thirty-five-year time span, one of Shepard's latest plays, that is, Heartless (2012) and A Particle of Dread, which had its première on November 28,2013 , still revolve around the concepts of intertextuality and re-presentation that frame the predominant themes of family secrets and demons of the past. 


\section{Works Cited}

Adler, Thomas P. "Repetition and Regression in Curse of the Starving Class and Buried Child." The Cambridge Companion to Sam Shepard. Ed. Matthew Roudané. Cambridge: Cambridge University Press, 2002. 111-122. Print.

Aercke, Kristiaan P. Gods of Play: Baroque Festive Performances as Rhetorical Discourse. Albany: State University of New York Press, 1994. Print.

Agamben, Giorgio. Infancy and History: The Destruction of Experience. Trans. Liz Heron. London and New York: Verso, 1993. Print.

Auerbach, Doris. "Who Was Icarus' Mother? The Powerless Mother Figures in the Plays of Sam Shepard." Bloom's Major Dramatists. Sam Shepard. Ed. Harold Bloom. Philadelphia: Chelsea House Publishers, 2003. 43-45. Print.

Bednarek, Bogusław. "Kwalifikatory uczty. Przyczynek do sympozjologii." Oczywisty urok biesiadowania. Ed. Piotr Kowalski. Wrocław: Towarzystwo Przyjaciół Polonistyki Wrocławskiej, 1998. 10-19. Print.

Blau, Herbert. The Dubious Spectacle: Extremities of Theater, 1976-2000. Minneapolis and London: University of Minnesota Press, 2002. Print.

Bottoms, Stephen J. The Theater of Sam Shepard: States of Crisis. Cambridge: Cambridge University Press, 1998. Print.

Bruster, Douglas. "The Dramatic Life of Objects in the Early Modern Theater." Staged Properties in Early Modern English Drama. Ed. Jonathan Gil Harris and Natasha Korda. Cambridge: Cambridge University Press, 2002. 67-96. Print.

Calabrese, Omar. Neo-Baroque: A Sign of the Times. Trans. Charles Lambert. Princeton: Princeton University Press, 1992. Print.

Cima, Gay Gibson. "Shifting Perspectives: Combining Shepard and Rauschenberg."

Theater Journal 38.1 (1986): 67-81. Print.

Deleuze, Gilles, and Felix Guattari. Kafka: Toward a Minor Literature. Trans. Dana Polan. Minneapolis: The University of Minnesota Press, 1986. Print.

Drakakis, John. "Introduction." Gothic Shakespeares. Ed. John Drakakis and Dale Townshend. Abingdon: Routledge, 2008. 1-20. Print.

Egginton, William. The Theater of Truth: The Ideology of (Neo)Baroque Aesthetics.

Stanford: Stanford University Press , 2010. Print.

Elam, Keir. The Semiotics of Theater and Drama. New York: Methuen, 1983. Print.

Falk, Florence. "The Role of Performance in Sam Shepard's Plays." Theater Journal 33.2 (1981): 182-198. Print.

Hartley, Andrew James. "Philip Massinger's The Roman Actor and the Semiotics of Censored Theater." English Literary History 68 (2001): 359-376. Print.

Inverso, MaryBeth. The Gothic Impulse in Contemporary Drama. Ann Arbor: UMI Research Press, 1990. Print.

Issacharoff, Michael. Discourse as Performance. Stanford: Stanford University Press, 1989. Print.

Lyons, John D. "Unseen Space and Theatrical Narrative: The 'Récit de Cinna."” Yale French Studies 80 (1991): 70-90. Print.

Looby, Robert. "Didaskalia w Kartotece Tadeusza Różewicza." Teksty Drugie 132.6 (2011): 201-214. Print. 
Krasner, David. American Drama 1945-2000: An Introduction. Oxford: Blackwell Publishing, 2006. Print.

Kristeva, Julia. "Modern Theatre Does Not Take (a) Place." Mimesis, Masochism \& Mime. The Politics of Theatricality in Contemporary French Thought. Ed. Timothy Murray. Michigan: University of Michigan Press, 2000. 277-281. Print.

Marranca, Bonnie. “Alphabetical Order: The Play of Words.” Performing Arts Journal 5.2 (1981): 8-25. Print.

McDonough, Carla J. "Patriarchal Pathology from The Holy Ghostly to Silent Tongue." The Cambridge Companion to Sam Shepard. Ed. Matthew Roudané. Cambridge: Cambridge University Press, 2002. 154-170. Print.

Murray, Timothy. Theatrical Legitimation: Allegories of Genius in SeventeenthCentury England and France. New York and Oxford: Oxford University Press, 1987. Print.

Panigrahi, Prasad Ramesh. The Splintered Self: Character and Vision in Sam Shepard's Plays. Delhi: Abhijeet Publications, 2004. Print.

Pavis, Patrice. "Play within a play." Def. Dictionary of the Theater: Terms, Concepts, and Analysis. Trans. Christine Shantz. Toronto: University of Toronto Press, 1998. Print.

Roudané, Matthew. The Cambridge Companion to Sam Shepard. Cambridge: Cambridge University Press, 2002. Print.

Sauer, David K. American Drama and the Postmodern: Fragmenting the Realistic Stage. Amherst and New York: Cambria Press, 2011. Print.

Schroeder, Patricia R. "Legitimizing the Bastard Child: Two New Looks at American Drama." American Literary History 3.2 (1991): 420-427. Print.

Shepard, Sam. Buried Child. Sam Shepard. Seven Plays. New York: The Dial Press, 2005. 61-132. Print.

Simard, Rodney. Postmodern Drama: Contemporary Playwrights in America and Britain. Lanham, London: University Press of America, 1984. Print.

Smith, Susan Harris. American Drama: The Bastard Art. New York: Cambridge University Press, 1997. Print.

- "Generic Hegemony: American Drama and the Canon." American Quarterly 41.1 (1989): 112-122. Print.

Spadaccini, Nicholas, and Luis Martín-Estudillo. "Introduction." Hispanic Baroques. Reading Cultures in Context. Ed. Nicholas Spadaccini and Luis MartínEstudillo. Nashville: Vanderbilt University Press, 2005. ix-xxxvi. Print.

Stone, George Winchester, Jr. "Lag and Change: Standards of Taste in Early American Drama." Educational Theater Journal 28.3 (1976): 338-346. Print.

Turner, Frederick Jackson. The Frontier in American History. 1893. Web. 30 Jan 2014. http://xroads.virginia.edu/ HYPER/TURNER/

Ubersfeld, Anne. Reading Theater. Trans. Frank Collins. Toronto: University of Toronto Press, 1999. Print.

Vanden Heuvel, Michael. "Complementary Spaces: Realism, Performance and a New Dialogics of Theater." Theater Journal 44.1 (1992): 47-58. Print. 
Williams, Anne. Art of Darkness: A Poetics of Gothic. Chicago and London: University of Chicago Press, 1995. Print.

Williamson, George. "Mutability, Decay, and Seventeenth-Century Melancholy." A Journal of English Literary History 2.2 (1935): 121-150. Print. 
